\title{
Physical Properties of Soy-Phosphate Polyol-Based Rigid Polyurethane Foams
}

\author{
Hongyu Fan, ${ }^{1}$ Ali Tekeei, ${ }^{2}$ Galen J. Suppes, ${ }^{2}$ and Fu-Hung Hsieh ${ }^{1}$ \\ ${ }^{1}$ Department of Biological Engineering, University of Missouri-Columbia, 248 AE Building, Columbia, MO 65211, USA \\ ${ }^{2}$ Department of Chemical Engineering, University of Missouri-Columbia, W2033 Lafferre Hall, Columbia, MO 65211, USA
}

Correspondence should be addressed to Fu-Hung Hsieh, hsiehf@missouri.edu

Received 28 October 2011; Accepted 21 December 2011

Academic Editor: Jose Ramon Leiza

Copyright (C) 2012 Hongyu Fan et al. This is an open access article distributed under the Creative Commons Attribution License, which permits unrestricted use, distribution, and reproduction in any medium, provided the original work is properly cited.

\begin{abstract}
Water-blown rigid polyurethane (PU) foams were made from 0-50\% soy-phosphate polyol (SPP) and 2-4\% water as the blowing agent. The mechanical and thermal properties of these SPP-based PU foams (SPP PU foams) were investigated. SPP PU foams with higher water content had greater volume, lower density, and compressive strength. SPP PU foams with $3 \%$ water content and $20 \%$ SPP had the lowest thermal conductivity. The thermal conductivity of SPP PU foams decreased and then increased with increasing SPP percentage, resulting from the combined effects of thermal properties of the gas and solid polymer phases. Higher isocyanate density led to higher compressive strength. At the same isocyanate index, the compressive strength of some 20\% SPP foams was close or similar to the control foams made from VORANOL 490.
\end{abstract}

\section{Introduction}

Polyurethanes (PU) are important chemical products and over three quarters of the PU are consumed in the form of foams globally [1]. Isocyanates and polyols are two major components in polyurethane (PU) production, and they both rely on petroleum as feedstocks [2-4]. In recent years, various factors motivate foam researchers to investigate potential and renewable resources as feedstocks of polyols. United States is a major producer of soybean oils and the price of soybean oil is forecasted to be relatively stable, ranging near \$9.20-9.25 per bushel in the next decade [5]. Besides, refined soybean oils contain more than $99 \%$ triglycerides with active sites amenable to chemical reactions [6]. Therefore, soybean oil (SBO) is one of the most promising biobased resources as a feedstock of polyols for PU manufacture. Several synthetic approaches have been reported to introduce hydroxyl groups to the triglycerides: (1) hydroformylation followed by hydrogenation [7], (2) epoxidation followed by oxirane opening [8-10], (3) ozonolysis followed by hydrogenation $[11,12]$, and (4) microbial conversion [13]. It has been reported that flexible and rigid PU foams could be made with a mixture of petroleum polyol and soybean oil-based polyols [14-16].
Soy-phosphate polyol (SPP) is made from the SBO-derived epoxides with the presence of phosphate acid as catalyst by acidolysis reaction. Normally, the acidolysis reaction is carried out by mixing SBO-derived epoxides, o-phosphate acid $\left(\mathrm{o}-\mathrm{H}_{3} \mathrm{PO}_{4}\right)$, water, and polar solvents, and the oligomerization occurs instantly to produce clear, viscous, homogeneous SPP with a low acid value and high average functionality. In this reaction, $\mathrm{SBO}$-derived epoxide is able to directly react with water to form diols because of their high reactivity through cleavage of the oxirane ring [17]. Phosphoric acid not only catalyzes ring-opening reaction but also is chemically involved to become part of the polyol $[18,19]$. Guo et al. $[19,20]$ prepared SPP by using water and a significant amount of polar solvents to obtain high hydroxyl functionality while keeping the final acid value low.

The distilled water, acting as blowing agent, reacts with isocyanate to generate carbon dioxide, which blows the reactant mixture to form a cellular structure. It is an important parameter that influences the properties and performance of rigid PU foams. By varying the amount of distilled water, Thirumal et al. [21] studied the effect of foam density on the properties of rigid PU foams made from a petroleum polyol. They found that the strength properties increase with the increase in density of the foams and their relationship can 
be roughly depicted by the Power law $[22,23]$. Campanella et al. [24] analyzed the effect of foaming variables, such as water content, polyol reactivity, catalyst, surfactant, and isocyanate, on the structure and properties of soybean oil-based PU foams. Water was used as a reactive blowing agent to produce $\mathrm{CO}_{2}$ with isocyanate. They found that an increase in the water content produced more $\mathrm{CO}_{2}$ and resulted in a larger foam volume as well as lower foam density. Also, the foam morphology was influenced by the water content. An increase in the water content produced rigid PU foams with thinner foam cell walls and larger foam cells, changing the density and morphology of the foams.

Isocyanate, which is derived from petroleum, is another critical component in PU production. Its amount (or the isocyanate index) and property greatly affected the performance of PU foams [25, 26]. Guo et al. [27] investigated effect of isocyanate index (ranging from 110 to 130) on compressive strength of rigid PU foams made from soybean-oil-based polyol. They found that compressive strength of soy-polyolbased foams varied proportionally with isocyanate index when isocyanate index was over 100, indicating that the mechanical property of rigid foams could be modified by altering the amount of isocyanate used in the foaming formulation. They concluded that excess isocyanate used in the foam formulation gave rise to a more rigid structure in rigid $\mathrm{PU}$ foams because of the more complete conversion of $\mathrm{OH}$ groups in polyols and the reaction of isocyanate with moisture in the air. Tu et al. [28] studied the physical properties of water-blown rigid $\mathrm{PU}$ foams containing epoxidized soybean oil with an isocyanate index ranging from 50 to 110 . They reported that the foam density decreased when the isocyanate index decreased to 60, but a sharp increase in density occurred at isocyanate index 50 due to foam shrinkage. Also, the compressive strength decreased with decreasing isocyanate index. Decreasing the isocyanate index would reduce isocyanate and meanwhile increase the bio-based content in PU formulations. In this study, the objective was to investigate the effect water (blowing agent) content and isocyanate index on the physical properties of SPP PU foams.

\section{Materials and Methods}

2.1. Materials. The petroleum-based polyol and isocyanate used in this study were VORANOL 490 and PAPI 27, respectively. Both were obtained from Dow Chemical Co. (Midland, MI). Their specifications are shown in Tables 1 and 2 , respectively. Soy-phosphate polyol (SPP) was prepared at the University of Missouri and its specification is shown in Table 3. It was made by an acidolysis reaction as shown in Figure 1 [18]. Full-epoxidized soybean oil (7.0\% oxirane, Vikoflex 7170, Arkema, King of Prussia, PA) was reacted with $1.5 \%$ o- $\mathrm{H}_{3} \mathrm{PO}_{4}$ (85\% aqueous from Fisher Scientific), added drop wise in a beaker under vigorous mechanical stirring at room temperature for $5 \mathrm{~min}$ [18]. Dimethylcyclohexylamine and pentamethyldiethylenetriamine were used as catalysts. They were from Sigma-Aldrich (St. Louis, MO). Dabco DC 5357 (Air Products and Chemicals, Allentown, PA) was used as a surfactant.
TABLE 1: Specifications of polymeric isocyanate PAPI 27 [29].

\begin{tabular}{ll}
\hline Properties & Values \\
\hline Density, g/mL at $25^{\circ} \mathrm{C}$ & 1.23 \\
Average molecular weight & 340 \\
Functionality & 2.7 \\
$\mathrm{NCO}$ content by weight, $\%$ & 31.4 \\
Viscosity, cps at $25^{\circ} \mathrm{C}$ & $150-220$ \\
Acidity, $\%$ & 0.017 \\
Vapor pressure, $\mathrm{mm} \mathrm{Hg}$ at $25^{\circ} \mathrm{C}$ & $<10^{-5}$ \\
Decomposition point & ${ }^{\circ} \mathrm{C}$ \\
\hline
\end{tabular}

TABLe 2: Specifications of VORANOL 490 [30].

\begin{tabular}{ll}
\hline Properties & Values \\
\hline Density, g/cm ${ }^{3}$ & 1.11 \\
Hydroxyl number, mg KOH/g & 484.8 \\
Functionality & 4.3 \\
Average molecular weight, g & 460 \\
Flash point, $0^{\circ} \mathrm{C}$ & 31.4 \\
Water content, $\%$ & 0.007 \\
Viscosity, $\mathrm{mPa} . \mathrm{s}\left(\right.$ at $\left.25^{\circ} \mathrm{C}\right)$ & 6180 \\
\hline
\end{tabular}

TABLE 3: Specifications of soy-phosphate polyol [18].

\begin{tabular}{ll}
\hline Properties & Values \\
\hline Hydroxyl number, $\mathrm{mg} \mathrm{KOH} / \mathrm{g}$ & 240 \\
Viscosity, $\mathrm{mPa} \cdot \mathrm{s}\left(\right.$ at $\left.25^{\circ} \mathrm{C}\right)$ & 3946.8 \\
Acid number & 0.5 \\
\hline
\end{tabular}

2.2. Experimental Design and Foaming Formulations. This experiment consisted of two stages. In the first stage, the effect of water content $(2,3$, and $4 \%)$ with different soy-phosphate polyol (SPP) percentages $(0,10,20,30,40$, and $50 \%)$ on the properties of rigid PU foams were studied. Table 4 shows the foaming formulations for rigid SPP-based polyurethane foams (SPP PU foams). Based on the results obtained from the first stage, the water content was fixed at $3 \%$ at the second stage to study the effect of isocyanate index and SPP percentage on the properties of SPP PU foams. The formulations are shown in Table 5.

2.3. Foam Preparation. The water-blown rigid polyurethane foams were made through one-shot and free-rising method. A total of $100 \mathrm{~g}$ of VORANOL 490 and soy-polyol mixture were weighed in a plastic container. Other B-side components such as water, catalysts, and surfactant were added successively and all B-side materials were mixed with an electric mixer at $3450 \mathrm{rpm}$ for $2 \mathrm{~min}$. The mixture was allowed to degas for $2 \mathrm{~min}$. Thereafter, preweighed isocyanate (A-side material) was added rapidly and mixed at the same speed for $10 \mathrm{~s}$. Then, the reacting mixture was poured quickly into a wooden mold $(11.4 \times 11.4 \times 21.6 \mathrm{~cm})$ with aluminum lining and the foam was allowed to free-rise and set at ambient 


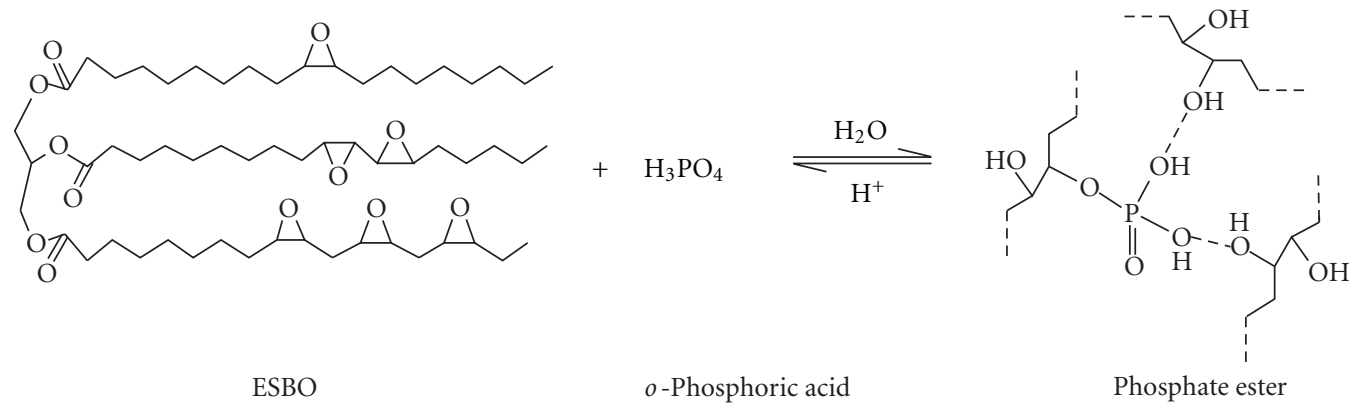

FIGURE 1: Schematic representation of soy-phosphate formation.

TABLE 4: Foaming formulation of rigid polyurethane foams with different soy-phosphate polyol percentages.

\begin{tabular}{|c|c|c|}
\hline Ingredients & \multicolumn{2}{|c|}{ Parts by weight ${ }^{\mathrm{a}}$} \\
\hline$B$-side materials & Control PU foams & SPP PU foams \\
\hline $\begin{array}{l}\text { VORANOL } 490 \\
\text { (petroleum-based polyol) }\end{array}$ & 100 & $90,80,70,60,50$ \\
\hline $\begin{array}{l}\text { Soy-phosphate poyol (soybean } \\
\text { oil-based polyol) }\end{array}$ & 0 & $10,20,30,40,50$ \\
\hline $\begin{array}{l}\text { Dimethylcyclohexylamine } \\
\text { (gelling catalyst) }\end{array}$ & 0.84 & 0.84 \\
\hline $\begin{array}{l}\text { Pentamethyldiethylenetriamine } \\
\text { (blowing catalyst) }\end{array}$ & 1.26 & 1.26 \\
\hline Dabco DC 5357 (surfactant) & 2.5 & 2.5 \\
\hline Distilled water (blowing agent) & $2.0,3.0,4.0$ & $2.0,3.0,4.0$ \\
\hline A-side material & & \\
\hline Isocyanate index ${ }^{\mathrm{b}}$ of PAPI 27 & 110 & 110 \\
\hline
\end{tabular}

aAll recipes and calculations are based on 100 total parts by weight of polyol, which conventionally dictates that the sum of all polyols adds up to 100 parts.

${ }^{b}$ The amount of isocyanate is based on the isocyanate index. The isocyanate index is the amount of isocyanate used relative to the theoretical equivalent amount.

TABLE 5: Foaming formulation of rigid polyurethane foams with different isocyanate indices.

\begin{tabular}{|c|c|c|}
\hline Ingredients & \multicolumn{2}{|c|}{ Parts by weight ${ }^{\mathrm{a}}$} \\
\hline B-side materials & Control PU foams & SPP PU foams \\
\hline $\begin{array}{l}\text { VORANOL } 490 \\
\text { (petroleum-based polyol) }\end{array}$ & 100 & 80,50 \\
\hline $\begin{array}{l}\text { Soy-phosphate poyol (soybean } \\
\text { oil-based polyol) }\end{array}$ & 0 & 20,50 \\
\hline $\begin{array}{l}\text { Dimethylcyclohexylamine } \\
\text { (gelling catalyst) }\end{array}$ & 0.84 & 0.84 \\
\hline $\begin{array}{l}\text { Pentamethyldiethylenetriamine } \\
\text { (blowing catalyst) }\end{array}$ & 1.26 & 1.26 \\
\hline Dabco DC 5357 (surfactant) & 2.5 & 2.5 \\
\hline Distilled water (blowing agent) & 3.0 & 3.0 \\
\hline A-side material & & \\
\hline Isocyanate index ${ }^{\mathrm{b}}$ of PAPI 27 & $70,80,90,100,110$ & $70,80,90,100,110$ \\
\hline
\end{tabular}

conditions $\left(23^{\circ} \mathrm{C}\right)$ for 7 days before measurement except thermal conductivity which was conducted within $24-48 \mathrm{~h}$.

2.4. Foam Property Measurements. The apparent density of foam samples was measured according to the American Society of Testing Materials (ASTM) designation: D1622-08
(2008) [31]. The apparent thermal conductivity of rigid foams $(20 \times 20 \times 2.5 \mathrm{~cm})$ was determined according to ASTM designation: C518-10 [32] and was tested by a Fox 200 heat flow meter instrument (LaserComp, Wakefield, MA), after foam curing at room temperature $\left(25^{\circ} \mathrm{C}\right)$ for $24-48 \mathrm{~h}$. The compressive strength was determined according to ASTM Designation: D1621-10 [33] by a TA.HDi Texture 
Analyzer (Texture Technologies Corp., Scarsdale, NY). The compressive strength was also tested after foam was stored seven days at room temperature. The dimension of the specimen in both density and compressive strength was $6.35 \times$ $6.35 \times 3.81 \mathrm{~cm}$. Five specimens per sample were measured and the average was reported.

\section{Results and Discussion}

\subsection{Effect of Water Content}

3.1.1. Density. Figure 2 shows the effect of soy-phosphate polyol (SPP) percentage on the density of rigid PU foams with different water contents. At $2 \%$ water content, the density of PU foams decreased slightly with increasing SPP percentage. Because SPP has a lower hydroxyl number $(\mathrm{OH}$ number of 240) than the petroleum-based polyol, VORANOL 490 (OH number of 490), a higher percentage of SPP would require less isocyanate in the foam formulation. Furthermore, when the water content was fixed at $2 \%$, the same amount of carbon dioxide was generated in the PU foams. Thus, all foam volumes remained essentially the same and the density of foams decreased slightly with an increase in SPP percentage. However, at 3\% water content, the density of foams did not change significantly with increasing SPP percentage. In principle, higher water content in the foaming formulation process generated more volume or amount of carbon dioxide gas [34]. More carbon dioxide forced the cell walls of the foams to become thinner, causing a weaker threedimensional network, which led to decreased closed cell percentage (Figure 3) [35-37]. Even though less isocyanate was present to take part in foaming with increasing SPP percentage, the foam volume still decreased due to increase in the open cell percentage. The effects of both decreasing amount of isocyanate and foam volume caused the density to remain more or less the same. At 4\% water content, the density of foams did not change significantly except the foam with 50\% SPP replacement. This was caused by the same reason as $3 \%$ water content, which was discussed above. When SPP replacement reached $50 \%$, the closed cell content was only $60 \%$ (Figure 3 ) resulting in a much lower volume compared to other replacements. Therefore, the foam with $50 \%$ SPP replacement displayed a slightly higher density.

3.1.2. Closed Cell Percentage and Thermal Conductivity. The effect of SPP percentage on the closed cell percentage and thermal conductivity of rigid PU foams with different water contents was shown in Figures 3 and 4, respectively. In the foaming process, water reacted with isocyanate to produce carbon dioxide, which expanded the gelling polymer creating many small cells in the foam. At the same water content, the closed cell percentage of PU foams decreased with increasing SPP percentage. The functional hydroxyl groups of SPP were secondary, while in VORANOL 490 they were primary [38, 39]. It is known that the primary hydroxyl groups react three times faster than secondary groups with isocyanate $[37,40]$. The lower reactivity between the SPP and isocyanate might have diminished the foam cell strength and meanwhile given

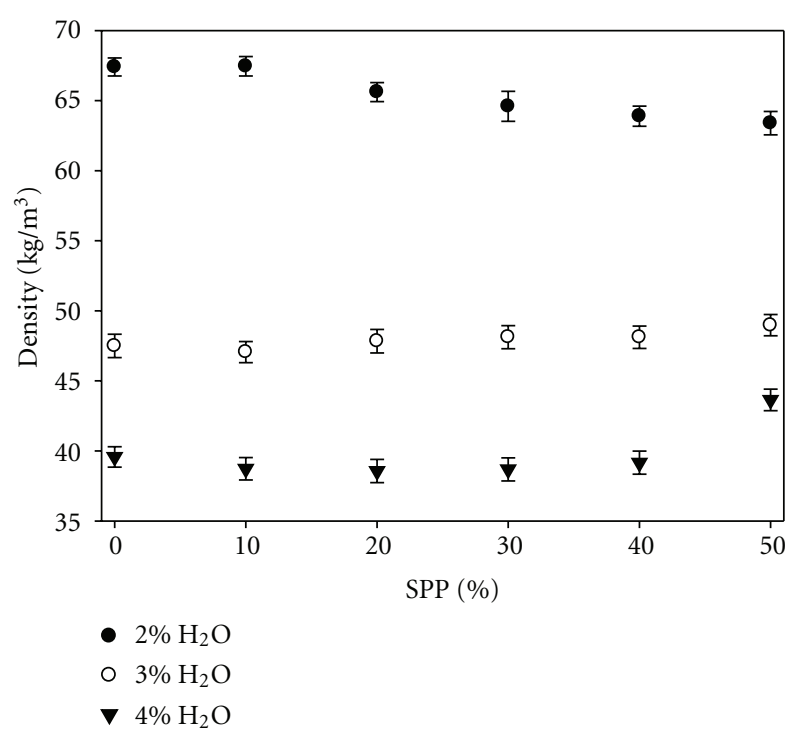

FIGURE 2: Effect of SPP percentage on density of rigid PU foams with different water contents.

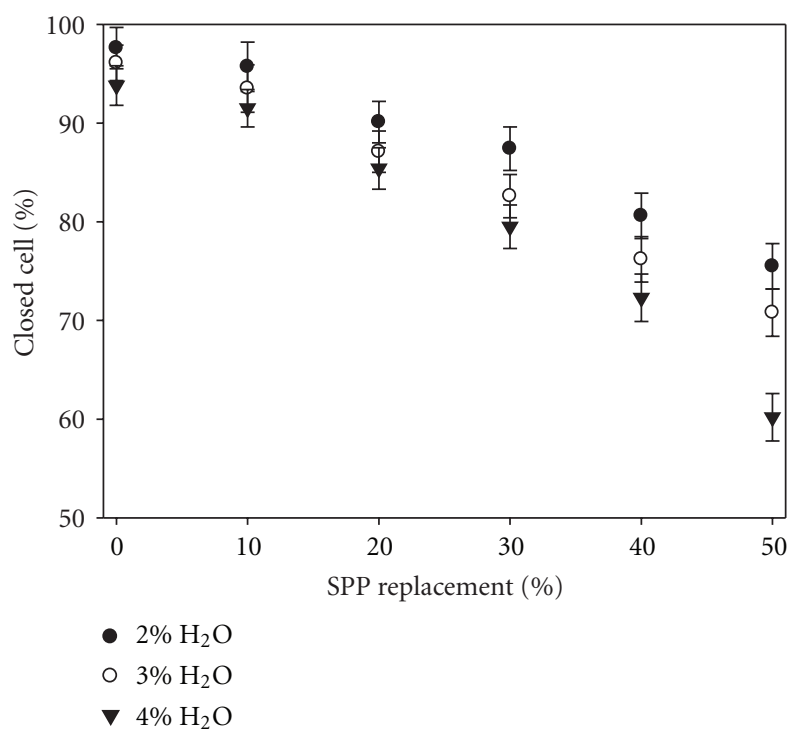

FIGURE 3: Effect of SPP percentage on closed cell percentage of rigid $\mathrm{PU}$ foams with different water contents.

rise to a weaker three-dimensional polymer network of cell walls to hold the pressure of carbon dioxide trapped in the cells. Therefore, with an increase of SPP percentage, the closed cell percentage in PU foams decreased.

The closed cell percentage decreased with increase in the water content. This was because at a higher water content, more carbon dioxide was generated leading to a larger foam volume and thinner cell walls. Thinner cell walls and higher gas volume might have weakened foam cell walls resulting in a lower closed cell percentage.

In Figure 4, at 2 to $4 \%$ water content, the thermal conductivity decreased from 0 to 20 or $30 \%$ SPP percentage and then increased. The thermal conductivity was mainly affected 


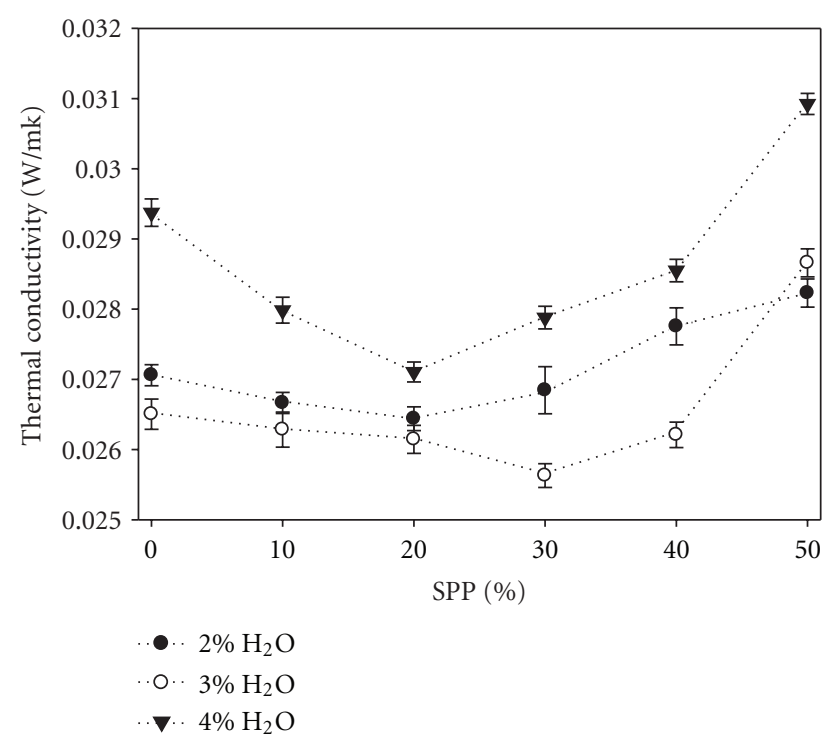

FIGURE 4: Effect of SPP percentage on thermal conductivity of rigid PU foams with different water contents.

by two factors: the conduction of the polymer phase and convection of the gas trapped in the cells [37, 41]. With increasing SPP percentage in the foam formulation process, less isocyanate was present to participate in the polymerization leading to less polymer phase. Therefore, the thermal conductivity was reduced when increasing the SPP percentage from 0 to 20 or $30 \%$. On the other hand, the amount of carbon dioxide trapped in the foams decreased with increasing SPP percentage due to lower closed cell percentage (Figure 3). Carbon dioxide has a lower thermal conductivity $(\sim 0.0146 \mathrm{~W} / \mathrm{mK})$ than air $(\sim 0.024 \mathrm{~W} / \mathrm{mK})$ at room temperature [42]. The thermal conductivity of SPP PU foams was contributed by both polymer phase and gas phase. When the SPP was higher than 20 or $30 \%$, the effect of decreasing closed cells (less carbon dioxide in the foam) might have exceeded the effect of decreasing polymer phase. This led to a higher thermal conductivity.

It is interesting to note that the thermal conductivity of foams at $3 \%$ water content was lower than those at $2 \%$ and followed by those at $4 \%$ at the same SPP percentage. As mentioned above, thinner cell walls (also less polymer phase) or higher closed cell percentage contributes to a lower thermal conductivity. Higher water content produced more gas, larger foam volume, and, therefore, thinner cell walls in the foam. At $4 \%$ water content, foams had the lowest closed cell percentage but more gas volume. At $2 \%$ water content, foams had the highest closed cell percentage but the lease amount of carbon dioxide trapped in the cells as well as the thickest cell wall. It appears foams at 3\% water content had the lowest thermal conductivity was due to the balanced effects from the closed cell percentage and amount if gas trapped in the cells.

3.1.3. Compressive Strength. Figure 5 shows the effect of SPP percentage on the compressive strength of rigid PU foams with different water contents. At 2\% water content, the compressive strength decreased with increasing SPP percentage.

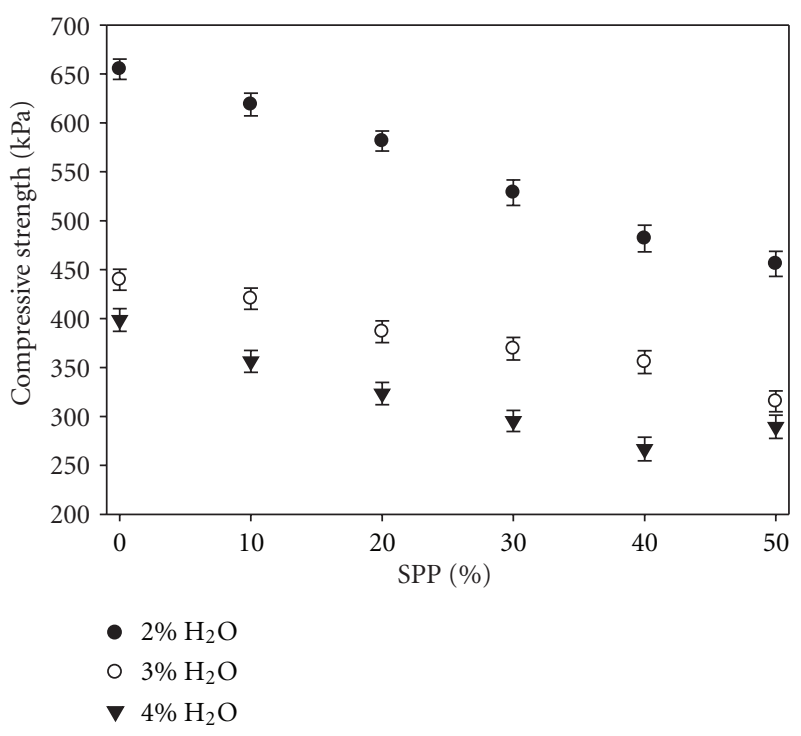

FIGURE 5: Effect of SPP percentage on compressive strength of rigid $\mathrm{PU}$ foams with different water contents.

Density and the number of cross-links of polymer network are two main factors that affect property of compressive strength of PU foams. Higher density and/or more crosslinks give rise to a higher compressive strength $[43,44]$. As the SPP percentage increased, less isocyanate was present in foaming. Therefore, fewer cross-links were generated by the reaction of hydroxyl and isocyanate functional groups [15, 45]. In addition, the foam density decreased slightly as the SPP percentage increased (Figure 2). Therefore, with increasing SPP percentage, the compressive strength decreased, due to both decreases of cross-links and density in PU foams.

Increasing the water content from 2 to $4 \%$ reduced the compressive strength (Figure 5). This was mainly due to the effect of water content on the foam density-higher density would result in higher compressive strength. As shown in Figure 2, the density of foams at $2 \%$ water content was higher than at $3 \%$ and followed by at $4 \%$. Therefore, the compressive strength of foams followed the same order.

In summary, the water content had a significant effect on the physical properties of SPP PU foams. Higher water content generated more carbon dioxide. Therefore, foams had larger volume, lower density, as well as lower compressive strength. Based on the previous results, SPP rigid PU foams with $3 \%$ water content had the best thermal conductivity, medium density, and compressive strength. Therefore, the effect of isocyanate index was investigated at $3 \%$ water content.

\subsection{Effect of Isocyanate Index}

3.2.1. Density. Figure 6 shows the effect of isocyanate index on the density of rigid PU foams at 20 and 50\% SPP. As shown, with the exception of 50\% SPP PU foam at index 70, foam density increased when increasing the isocyanate index. Increasing isocyanate index raised the actual amount of isocyanate in the polymerizing reaction, thereby increasing 


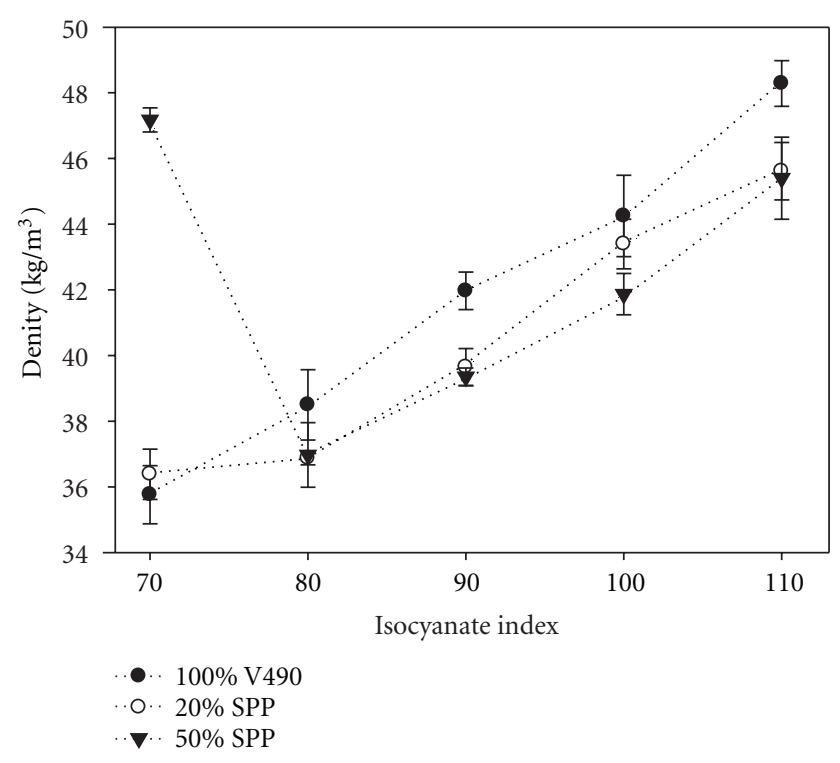

FIGURE 6: Effect of different isocyanate index on density of rigid PU foams with different SPP percentages.

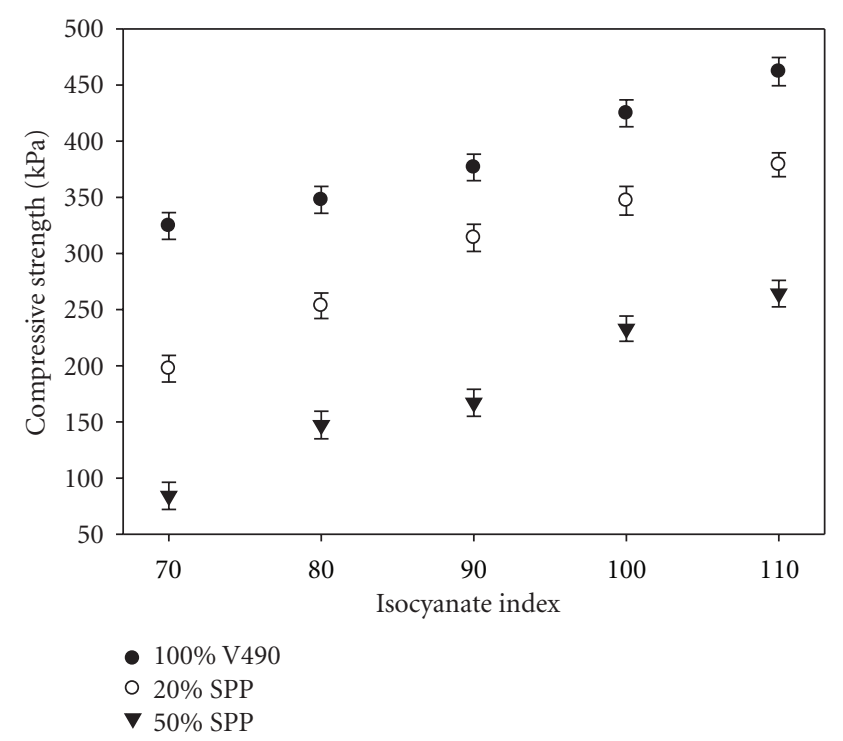

FIGURE 7: Effect of different isocyanate index on compressive strength of rigid PU foams with different SPP percentages.

the total amount of polymer network [46]. On the other hand, the foam volume was dictated by the amount of carbon dioxide generated by the reaction of water and isocyanate. This reaction was independent of the isocyanate index since isocyanate was not limiting when reacting with water. Therefore, the foam volume did not change with the SPP percentage which was also observed in the experiment. With more isocyanate in the foam formulation (increasing isocyanate index), foam density increased.

3.2.2. Compressive Strength. Figure 7 shows the effect of different isocyanate indices on compressive strength of rigid $\mathrm{PU}$

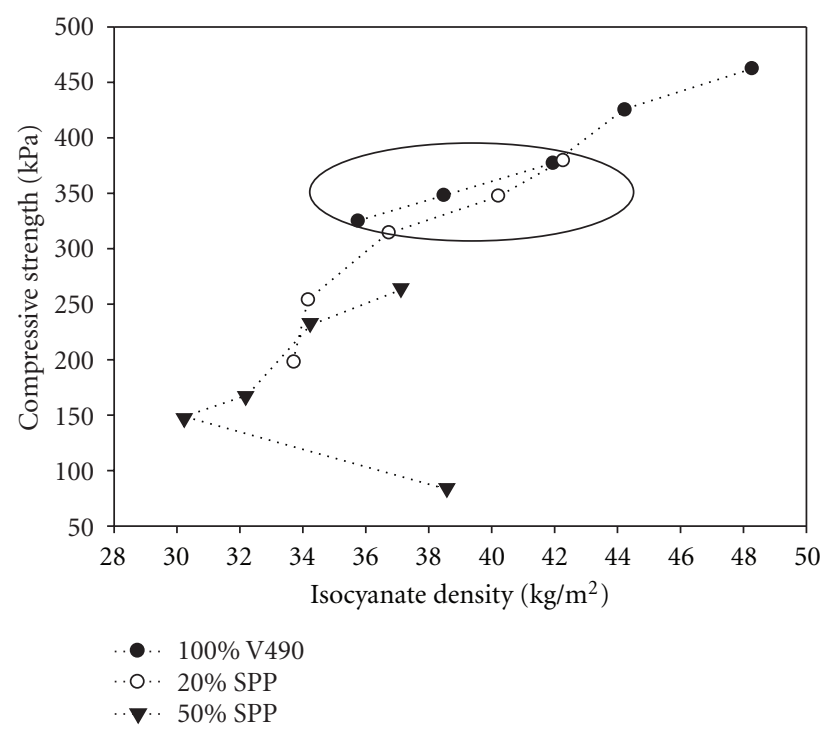

FIGURE 8: Results of compressive strength versus isocyanatye density.

foams at 20 and 50\% SPP. Raising the isocyanate index increased the compressive strength of foams. This was because the more the isocyanate used in the foam formulation, more cross-links were formed from the reaction of isocyanate and the hydroxyl groups in the polyols. In addition, foam density increased with the isocyanate index (Figure 6). Both increases in cross-links and density contributed to higher compressive strength.

The compressive strength of 50\% SPP foam was less than the $20 \%$ SPP foam and both SPP foams were less than the control (Figure 7). This might be due to the difference in the reactivity of isocyanate with the hydroxyl groups that were in the petroleum polyol in the control (primary) and those in the SPP (secondary). This might have resulted in less crosslinks when increasing the SPP percentage from 0 to $50 \%$. In addition, the density of control foam was also greater than the SPP foam leading to higher compressive strength.

3.2.3. Compressive Strength versus Isocyanate Density. Figure 8 displays the results of compressive strength versus isocyanate density of rigid PU foams. The isocyanate density was calculated by percent of isocyanate multiplying by the density of PU foams (Table 6). As shown, at the same SPP percentage, higher isocyanate density foams were harder or had higher compressive strength. While the compressive strengths of $50 \%$ SPP PU foams were always inferior to those of $100 \%$ VORANOL $490 \mathrm{PU}$ foams, it is interesting to note that some $20 \%$ SPP PU foams were close or similar to control in compressive strength at the same isocyanate density.

\section{Conclusion}

In summary, water-blown rigid polyurethane foams were produced by combining 0 to $50 \%$ soy-phosphate polyol (SPP) with petroleum-based-polyol VORANOL 490 using 
TABLE 6: Calculation of isocyanate density.

\begin{tabular}{|c|c|c|c|c|c|c|c|}
\hline SPP & $\begin{array}{l}\text { Isocyanate } \\
\text { index }\end{array}$ & $\begin{array}{c}\text { Foam } \\
\text { density } \\
\left(\mathrm{kg} / \mathrm{m}^{3}\right)\end{array}$ & $\begin{array}{l}\text { Theoretical } \\
\text { isocyanate } \\
\text { amount (g) }\end{array}$ & $\begin{array}{c}\text { Actual } \\
\text { isocyanate } \\
\text { amount (g) }\end{array}$ & $\begin{array}{l}\text { Isocyanate } \\
\text { mass fraction }\end{array}$ & $\begin{array}{c}\text { Isocyanate density } \\
\left(\mathrm{kg} / \mathrm{m}^{3}\right)=\text { Foam } \\
\text { density } \times \\
\text { isocyanate mass } \\
\text { fraction }\end{array}$ & $\begin{array}{l}\text { Compressive } \\
\text { strength }(\mathrm{kPa})\end{array}$ \\
\hline \multirow{5}{*}{0} & 110 & 48.29 & 176.62 & 176.62 & 1 & 48.29 & 461.99 \\
\hline & 100 & 44.25 & 160.57 & 160.57 & 1 & 44.25 & 424.79 \\
\hline & 90 & 41.97 & 144.50 & 144.50 & 1 & 41.97 & 376.59 \\
\hline & 80 & 38.5 & 128.45 & 128.45 & 1 & 38.50 & 347.71 \\
\hline & 70 & 35.77 & 112.40 & 112.40 & 1 & 35.77 & 324.48 \\
\hline \multirow{5}{*}{$20 \%$} & 110 & 45.62 & 176.62 & 163.73 & 0.93 & 42.29 & 379.04 \\
\hline & 100 & 43.40 & 160.57 & 148.85 & 0.93 & 40.23 & 346.97 \\
\hline & 90 & 39.65 & 144.50 & 133.97 & 0.93 & 36.76 & 313.95 \\
\hline & 80 & 36.88 & 128.45 & 119.08 & 0.93 & 34.19 & 253.47 \\
\hline & 70 & 36.39 & 112.40 & 104.20 & 0.93 & 33.73 & 197.40 \\
\hline \multirow{5}{*}{$50 \%$} & 110 & 45.40 & 176.62 & 144.40 & 0.82 & 37.12 & 264.28 \\
\hline & 100 & 41.87 & 160.57 & 131.28 & 0.82 & 34.23 & 232.98 \\
\hline & 90 & 39.36 & 144.50 & 118.15 & 0.82 & 32.18 & 167.07 \\
\hline & 80 & 36.98 & 128.45 & 105.02 & 0.82 & 30.23 & 147.29 \\
\hline & 70 & 47.18 & 112.40 & 91.88 & 0.82 & 38.56 & 84.15 \\
\hline
\end{tabular}

$2-4 \%$ water as the blowing agent. The results showed that the water content significantly affected the physical properties of the final SPP PU foams, such as density, compressive strength, and thermal conductivity-lowest water content produced foams with the least volume but the highest density and compressive strength. The lowest thermal conductivity was observed in SPP foams at 3\% water content. Because the hydroxyl number of SPP was lower than VORANOL 490, compressive strength of SPP foams decreased when increasing the SPP percentage in the foaming formulation. Increasing the isocyanate index or isocyanate density raised the compressive strength of SPP foams. At the same isocyanate index, the compressive strength of some $20 \%$ SPP foams was close or similar to the control foams made from VORANOL 490.

\section{Acknowledgments}

The authors thank the United Soybean Board for the financial support of this study. None of the authors has conflicts of interest with companies producing VORANOL 490, PAPI 27, Vikoflex 7170 and Dabco DC 5357.

\section{References}

[1] G. Avar, "Polyurethanes (PU)," Kunststoffe International, vol. 10, pp. 123-127, 2008.

[2] G. Woods, The ICI Polyurethane Book, John Wiley \& Sons, New York, NY, USA, 2nd edition, 1990.

[3] M. Szycher, Szycher's Handbook of Polyurethanes, CRC Press, Florida, Fla, USA, 1999.

[4] H. Ulrich, Introduction to Industrial Polymers, Hanser, New York, NY, USA, 1982.

[5] Economic Research Service, USDA, "Soybeans and oil crops: market outlook," 2010, http://www.ers.usda.gov/Briefing/ SoybeansOilcrops/2010_19baseline.htm.
[6] R. Wool and X. Sun, Bio-Based Polymers and Composites, Elsevier Academic Press, Mass, USA, 2005.

[7] A. Guo, D. Demydov, W. Zhang, and Z. S. Petrovic, "Polyols and polyurethanes from hydroformylation of soybean oil," Journal of Polymers and the Environment, vol. 10, no. 1-2, pp. 49-52, 2002.

[8] Z. Petrovic, I. Javni, A. Guo, and W. Zhang, "Method of making natural oil-based polyols and polyurethanes therefrom," US Patent no 6,433,121, 2002.

[9] Z. Lozada, G. J. Suppes, F. H. Hsieh, A. Lubguban, and Y. C. Tu, "Preparation of polymerized soybean oil and soy-based polyols," Journal of Applied Polymer Science, vol. 112, no. 4, pp. 2127-2135, 2009.

[10] A. A. Lubguban, Y. C. Tu, Z. R. Lozada, F. H. Hsieh, and G. J. Suppes, "Noncatalytic polymerization of ethylene glycol and epoxy molecules for rigid polyurethane foam applications," Journal of Applied Polymer Science, vol. 112, no. 4, pp. 21852194, 2009.

[11] Z. S. Petrović, W. Zhang, and I. Javni, "Structure and properties of polyurethanes prepared from triglyceride polyols by ozonolysis," Biomacromolecules, vol. 6, no. 2, pp. 713-719, 2005.

[12] S. S. Narine, X. Kong, L. Bouzidi, and P. Sporns, "Physical properties of polyurethanes produced from polyols from seed oils: I. Elastomers," Journal of the American Oil Chemists' Society, vol. 84, no. 1, pp. 55-63, 2007.

[13] C. T. Hou, "Microbial oxidation of unsaturated fatty acids," Advances in Applied Microbiology, vol. 41, pp. 1-23, 1995.

[14] Z. S. Petrović, L. Yang, A. Zlatanić, W. Zhang, and I. Javni, "Network structure and properties of polyurethanes from soybean oil," Journal of Applied Polymer Science, vol. 105, no. 5, pp. 2717-2727, 2007.

[15] L. L. Monteavaro, E. O. Da Silva, A. P. O. Costa, D. Samios, A. E. Gerbase, and C. L. Petzhold, "Polyurethane networks from formiated soy polyols: synthesis and mechanical characterization," Journal of the American Oil Chemists' Society, vol. 82, no. 5, pp. 365-371, 2005. 
[16] J. John, M. Bhattacharya, and R. B. Turner, "Characterization of polyurethane foams from soybean oil," Journal of Applied Polymer Science, vol. 86, no. 12, pp. 3097-3107, 2002.

[17] G. Knothe and J. Derksen, Recent Developments in the Synthesis of Fatty Acid Derivatives, AOCS Press, Ill, USA, 1999.

[18] A. Lubguban, Z. R. Lozada, Y. Tu, H. Fan, F. Hsieh, and GJ. I. Suppes, "Isocyanate reduction by epoxide substitution of alcohols for polyurethane bioelastomer synthesis," International Journal of Polymer Science, vol. 2011, Article ID 936973, 8 pages, 2011.

[19] Y. Guo, V. M. Mannari, P. Patel, and J. L. Massingill, "Selfemulsifiable soybean oil phosphate ester polyols for low-VOC corrosion resistant coatings," Journal of Coatings Technology Research, vol. 3, no. 4, pp. 327-331, 2006.

[20] Y. Guo, J. H. Hardesty, V. M. Mannari, and J. L. Massingill, "Hydrolysis of epoxidized soybean oil in the presence of phosphoric acid," Journal of the American Oil Chemists' Society, vol. 84, no. 10, pp. 929-935, 2007.

[21] M. Thirumal, D. Khastgir, N. K. Singha, B. S. Manjunath, and Y. P. Naik, "Effect of foam density on the properties of water blown rigid polyurethane foam," Journal of Applied Polymer Science, vol. 108, no. 3, pp. 1810-1817, 2008.

[22] F. Kurt and H. James, Plastic Foams, Marcel Dekker, New York, NY, USA, 1973.

[23] S. H. Goods, C. L. Neuschwanger, C. C. Henderson, and D. M. Skala, "Mechanical properties of CRETE, a polyurethane foam," Journal of Applied Polymer Science, vol. 68, no. 7, pp. 1045-1055, 1998.

[24] A. Campanella, L. M. Bonnaillie, and R. P. Wool, "Polyurethane foams from soyoil-based polyols," Journal of Applied Polymer Science, vol. 112, no. 4, pp. 2567-2578, 2009.

[25] I. Javni, W. Zhang, and Z. S. Petrović, "Effect of different isocyanates on the properties of soy-based polyurethanes," Journal of Applied Polymer Science, vol. 88, no. 13, pp. 2912-2916, 2003.

[26] T. W. Pechar, G. L. Wilkes, B. Zhou, and N. Luo, "Characterization of soy-based polyurethane networks prepared with different diisocyanates and their blends with petroleum-based polyols," Journal of Applied Polymer Science, vol. 106, no. 4, pp. 2350-2362, 2007.

[27] A. Guo, I. Javni, and Z. Petrovic, "Rigid polyurethane foams based on soybean oil," Journal of Applied Polymer Science, vol. 77, no. 2, pp. 467-473, 2000.

[28] Y. C. Tu, H. Fan, G. J. Suppes, and F. H. Hsieh, "Physical properties of water-blown rigid polyurethane foams containing epoxidized soybean oil in different isocyanate indices," Journal of Applied Polymer Science, vol. 114, no. 5, pp. 2577-2583, 2009.

[29] Dow Plastics, Product Information of PAPI 27 Polymeric MDI, The Dow Chemical Company, Midland, Mich, USA, 2001.

[30] Dow Plastics, PProduct Information of VORANOL 490, The Dow Chemical Company, Midland, Mich, USA, 2001.

[31] ASTM Designation: D1622-08, Standard Test Method for Apparent Density of Rigid Cellular Plastics, 2008.

[32] ASTM Designation: C518-10, Standard Test Method for Steady-State Thermal Transmission Properties by Means of the Heat Flow Meter Apparatus, 2010.

[33] ASTM Designation: D1621-10, Standard Test Method for Compressive Properties of Rigid Cellular Plastics, 2010.

[34] H. Youn, J. Lee, and S Choi., "Properties of rigid polyurethane foams blown by HFC-365mfc and distilled water," Journal of Industrial and Engineering Chemistry, vol. 13, no. 7, pp. 10761082, 2007.
[35] S. S. Narine, X. Kong, L. Bouzidi, and P. Sporns, "Physical properties of polyurethanes produced from polyols from seed oils: II. Foams," Journal of the American Oil Chemists' Society, vol. 84, no. 1, pp. 65-72, 2007.

[36] M. Thirumal, D. Khastgir, N. K. Singha, B. S. Manjunath, and Y. P. Naik, "Mechanical, morphological and thermal properties of rigid polyurethane Foam: effect of chain extender, polyol and blowing agent," Cellular Polymers, vol. 28, no. 2, pp. 145-158, 2009.

[37] Y. C. Tu, G. J. Suppes, and F. H. Hsieh, "Water-blown rigid and flexible polyurethane foams containing epoxidized soybean oil triglycerides," Journal of Applied Polymer Science, vol. 109, no. 1, pp. 537-544, 2008.

[38] Y. C. Tu, P. Kiatsimkul, G. Suppes, and F. H. Hsieh, "Physical properties of water-blown rigid polyurethane foams from vegetable oil-based polyols," Journal of Applied Polymer Science, vol. 105, no. 2, pp. 453-459, 2007.

[39] A. Guo, W. Zhang, and Z. S. Petrovic, "Structure-property relationships in polyurethanes derived from soybean oil," Journal of Materials Science, vol. 41, no. 15, pp. 4914-4920, 2006.

[40] R. Herrington and K. Hock, Dow Polyurethane Flexible Foams, The Dow Chemical Company, Midland, Mich, USA, 2nd edition, 1997.

[41] A. Biedermann, C. Kudoke, A. Merten et al., "Analysis of heat transfer mechanisms in polyurethane rigid foam," Journal of Cellular Plastics, vol. 37, no. 6, pp. 467-483, 2001.

[42] En.wikipedica.org, "List of thermal conductivities," 2010, http: //en.wikipedia.org/wiki/List_of_thermal_conductivities/.

[43] M. C. Hawkins, B. O’Toole, and D. Jackovich, "Cell morphology and mechanical properties of rigid polyurethane foam," Journal of Cellular Plastics, vol. 41, no. 3, pp. 267-285, 2005.

[44] H. Jin, W. Y. Lu, S. Scheffel, M. K. Neilsen, and T. D. Hinnerichs, "Characterization of mechanical behavior of polyurethane foams using digital image correlation," in Proceedings of the ASME International Mechanical Engineering Congress and Exposition (IMECE '05), vol. 256, pp. 293-298, Orlando, Fla, USA, November 2005.

[45] H. Lim, S. H. Kim, and B. K. Kim, "Effects of the hydroxyl value of polyol in rigid polyurethane foams," Polymers for Advanced Technologies, vol. 19, no. 12, pp. 1729-1734, 2008.

[46] D. V. Dounis and G. L. Wilkes, "Effect of toluene diisocyanate index on morphology and physical properties of flexible slabstock polyurethane foams," Journal of Applied Polymer Science, vol. 66, no. 13, pp. 2395-2408, 1997. 

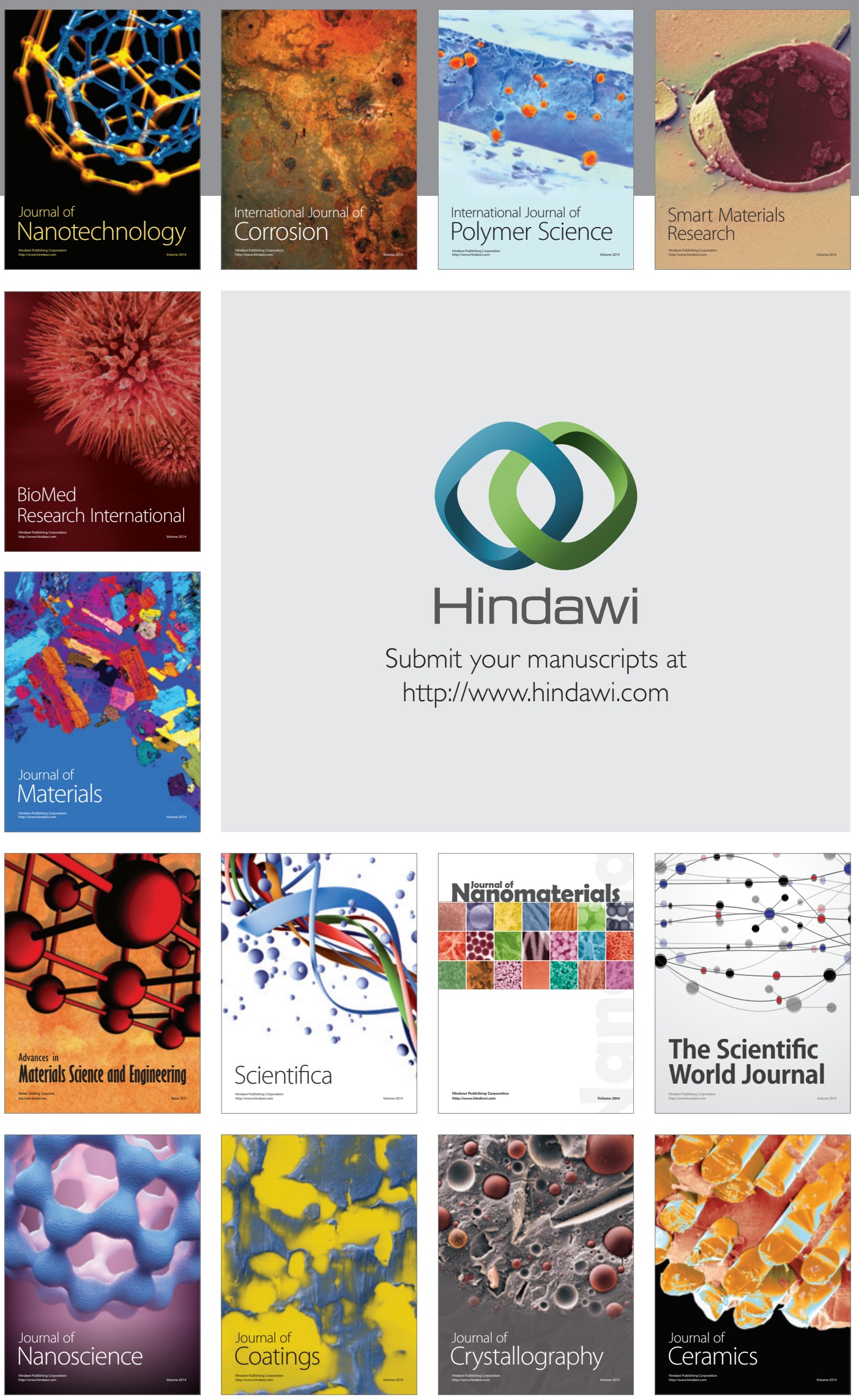

The Scientific World Journal

Submit your manuscripts at

http://www.hindawi.com

\section{World Journal}

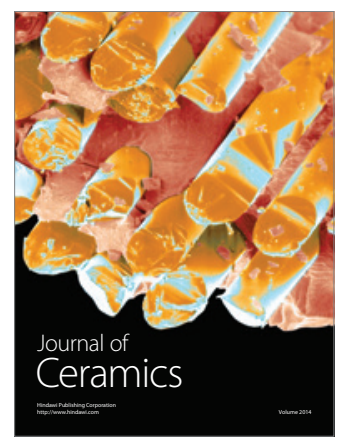

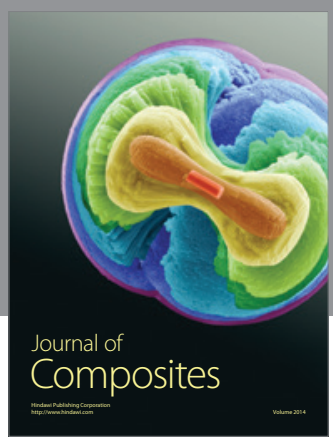
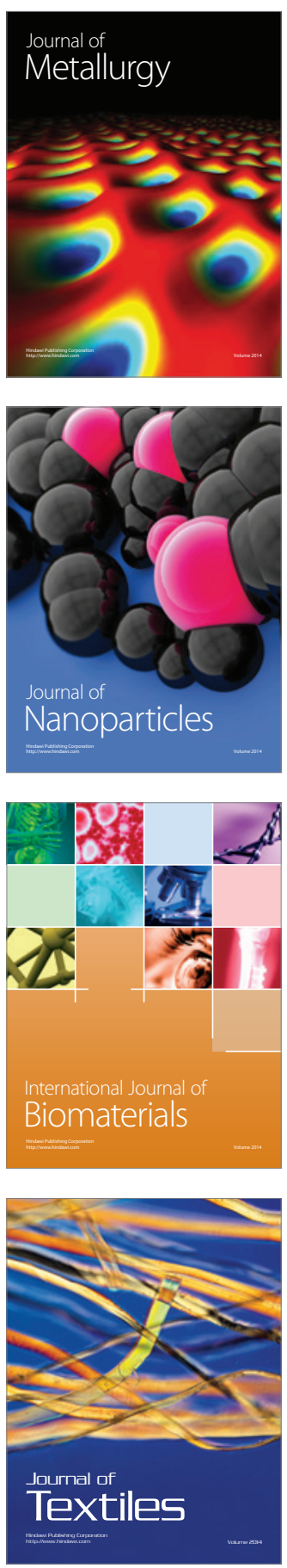